\title{
New Political Science
}

\section{Must We Talk about Populism? Interrogating Populism's Conceptual Utility in a Context of Crisis}

\section{Barry Cannon}

To cite this article: Barry Cannon (2018) Must We Talk about Populism? Interrogating Populism's Conceptual Utility in a Context of Crisis, New Political Science, 40:3, 477-496, DOI: 10.1080/07393148.2018.1487187

To link to this article: https://doi.org/10.1080/07393148.2018.1487187

曲 Published online: 03 Aug 2018.

Submit your article to this journal

Џll Article views: 284

View Crossmark data ¿ 


\title{
Must We Talk about Populism? Interrogating Populism's Conceptual Utility in a Context of Crisis
}

\author{
Barry Cannon
}

Department of Sociology, Maynooth University, Maynooth, Ireland

\begin{abstract}
John Gerring identifies eight criteria to help assess the utility of a concept: familiarity, resonance, parsimony, coherence, differentiation, depth, theoretical utility, and field utility. Populism has often been challenged on these despite much work done by scholars to help clarify and sharpen the concept. Nevertheless, three central criticisms persist: the term remains conceptually loose; analysis is often underpinned by an unacknowledged normative bias toward liberal democracy; and, the concept often acts as a label used to sideline challengers to the political status quo, despite crucial differences between these on socio-economic, political, and identity inequalities. Its conceptual utility is therefore questionable as so-called populism displaces the inequalities; particularly, political inequality, which originally engendered the phenomena in the first place. The article concludes by recommending a return to more traditional concepts such as the left/right axis to help redirect debate to more promising lines of inquiry, which can help resolve what I call the "crisis of inequalities."
\end{abstract}

\section{Introduction}

There is a specter haunting global politics, and some of the leading politicians in Europe and the Americas know it. President of the European Commission, ${ }^{1}$ Jean Claude Juncker, French ex-President, Francoise Hollande (2012-2017), ${ }^{2}$ Chancellor of Germany, ${ }^{3}$ Angela Merkel (2005-present), and, ex-US President, Barack Obama (2009-2017), ${ }^{4}$ are all convinced that populism is bad for democracy. The media seems to be equally concerned, with populism being mentioned in 695 headlines in the world's major English language news publications between January 1, 2015 and May 4, 2017..$^{5}$ Similar searches in

\footnotetext{
CONTACT Barry Cannon barry.cannon@mu.ie

${ }^{1}$ Holly Ellyat, "Europe Faces 'Galloping Populism,' Juncker Warns in State of the Union Address," CNBC (September 14, 2016), available online at: http://www.cnbc.com/2016/09/14/europe-faces-galloping-populism-juncker-warns-in-stateof-the-union-address.html.

${ }^{2}$ France 24, "France's Hollande Reacts to Trump Win, Calls for 'Unity' in Face of Rising Populism," France 24, International News 24/7 (November 16, 2016), available online at: http://www.france24.com/en/20161115-live-french-presidentfrancois-hollande-interview-france-24-tv5-monde-rfi.

${ }^{3}$ AFP, "Angela Merkel: The Rise of Populist Parties is Remarkable and Regrettable," The Journal.ie (May 26, 2014), available online at: http://www.thejournal.ie/angela-merkel-european-elections-1486214-May2014/.

${ }^{4}$ AFP, "Barack Obama Hits Out at 'Populist Strongmen' Vladimir Putin, Donald Trump in Last UN Address," ABC News (September 20, 2016), available online at: http://www.abc.net.au/news/2016-09-21/obama-hits-at-populist-strong men-in-last-un-address/7863656.

"Based on a Lexis Nexis search for "populism" conducted by the author during this period.

(c) 2018 Caucus for a New Political Science
} 
Spanish (results 2,618), French (663), Italian (709), and German (1,070) language news outlets also show considerable concern about the phenomenon. Populism has, of course, been of long-standing academic concern; particularly, in the post-World War II era, and most especially since the end of the Cold War. ${ }^{6}$ This concern continues unabated, with 1,865 academic resources in English with "populism" in the title published between 2013 and 2017. ${ }^{7}$

This article seeks to critically examine this concern. In particular, it seeks to question if the concept of populism remains a useful one for the social sciences in the current context of what I call the "crisis of inequalities." While the current consensus seems to suggest that the world is emerging from the impact of the 2008 financial crisis, ${ }^{8}$ socioeconomic inequality continues to rise on a global scale, albeit at different speeds. ${ }^{9}$ Moreover, socio-economic inequality is further crossed by gender, sexual, ethnic, and other inequalities, through what feminist scholars identify as intersectionality. ${ }^{10}$ Rising socio-economic inequality is important, as it "affects, and is affected by everything, from the growth of the economy, to the structure of the welfare state, to the involvement of citizens in the democratic process."11 On this last point alone, as: "Poor people, on average, vote less frequently than richer people,...a high level of inequality enhances this effect." ${ }^{12}$ This can result in endogenous political processes perpetuating high inequality, resulting in a vicious spiral of ever-reducing collective welfare and political exclusion of the poor. ${ }^{13}$

As a result of this crisis of inequalities, increasing popular disenchantment with actually existing liberal democracy has emerged. ${ }^{14}$ I understand liberal democracy here through the lens of William I. Robinson's critique of polyarchy, which "refers to a system in which a small group actually rules, on behalf of capital, and participation in decision-making by the majority is confined to choosing among competing elites in tightly controlled electoral processes." ${ }^{15}$ Polyarchy is being increasingly questioned by citizens in the post-Cold War contemporary context for three key reasons. ${ }^{16}$ First, there is a banishment of discourse on class from political debate, even as the policies enacted by political parties of the "extreme center"17 exacerbate class tensions and enrich a tiny

\footnotetext{
${ }^{6}$ Marco D’Eramo, "Populism and the New Oligarchy," New Left Review 82 (July-August 2013), pp. 5-28.

${ }^{7}$ Found in a WordCat search conducted by the author through Maynooth University.

${ }^{8}$ IMF, "World Economic Outlook Update," International Monetary Fund: World Economic Outlook (January 22, 2018), available online at: http://www.imf.org/en/Publications/WEO/Issues/2018/01/11/world-economic-outlook-update-jan uary-2018.

${ }^{9}$ Facundo Alvaredo, Lucas Chancel, Thomas Piketty, Emmanuel Saez, and Gabriel Zucman, World Inequality Report 2018: Executive Summary (World Inequality Lab, 2018), p. 4, available online at: http://wir2018.wid.world/files/download/ wir2018-summary-english.pdf.

${ }^{10}$ See for example Sylvia Walby, Jo Armstrong, and Sofia Strid, "Intersectionality: Multiple Inequalities in Social Theory," Sociology 46:2 (2012), pp. 224-40; Hae Yeon Choo and Myra Marx Ferree, "Practicing Intersectionality in Sociological Research: A Critical Analysis of Inclusions, Interactions, and Institutions in the Study of Inequalities," Sociological Theory 28:2 (2010), pp. 129-49. See also the Special Issue on "Intersectionality in the Global Age," New Political Science 37:4 (2015).

${ }^{11}$ Carsten Jensen and Kees van Kersbergen, The Politics of Inequality (London, UK; New York, NY: Palgrave Macmillan Educational, 2017), p. 2.

${ }^{12}$ Ibid., 5.

${ }^{13}$ John Echeverri-Gent, "Persistent High Inequality as an Endogenous Political Process," PS: Political Science and Politics 42:4 (2009), pp. 633-38.

${ }^{14}$ See for example Colin Crouch, Post-democracy (Cambridge, MA: Polity Press, 2004); Peter Mair, "Ruling the Void? The Hollowing of Western Democracy," New Left Review 42 (2006), pp. 25-51.

${ }^{15}$ William I. Robinson, "Latin America and Global Capitalism," Race and Class 40:2-3 (1998/99), pp. 111-31.

${ }^{16} \mathrm{D}^{\prime}$ Eramo, "Populism and the New Oligarchy," pp. 3-25.

${ }^{17}$ Tariq Ali, The Extreme Center: A Second Warning (London, UK; New York, NY: Verso, 2018).
} 
minority at the expense of the majority. Second, there is an expansion of "negative power" - that is, powers of prevention, surveillance, and evaluation - in favor of "independent" central banks and international financial institutions, such as the World Bank and the International Monetary Fund (IMF), as well as private ratings agencies, all of them unelected and unaccountable to citizens. Third, there is a substantial reduction of the scope of democratic decision-making, through a narrowing of party political programmatic differentiation, all of which must adhere to the dictates of the previously mentioned negative powers. The result has been the consolidation of an oligarchic regime that ensures that "the elites are not subject to the same legal regime as the rest of the population."18

This disenchantment with liberal democracy has been seen in Europe, with the emergence of many new left- and right-wing movements; in Latin America with the emergence of a "pink-tide" of left-wing governments, beginning with the election of Hugo Chávez in Venezuela in 1998; and, more recently in the United States (US) with the ascendance of Donald Trump to the presidency. What links these political phenomena is a rejection of actually existing liberal democracy and a search for a new, more popularly responsive democracy that can reverse the previously mentioned de-democratizing dynamics in some if not all of these areas of inequality. This can involve not only a minimalist model of elections, but also can include more direct and participatory forms of democracy, such as referenda or participatory budgeting, and more equitable socialeconomic outcomes. ${ }^{19}$ While these political phenomena have almost uniformly been labeled populist, I eschew such neat characterizations, and instead define populism as a theoretical academic tradition used, intentionally or not, to negatively counterpose electorally democratic but non-liberal political organizations with polyarchy. It is therefore an intellectual movement that prioritizes the protection of polyarchy over the eradication of the very inequalities, which give rise to these variegated political phenomena, and as such is a self-defeating exercise that can only be broken if social science abandons the concept and seeks more accurate conceptual tools, which can better help eradicate such inequalities.

The article will proceed in the following manner. First, I will give an overview of the different conceptual meanings ascribed to populism historically, arguing that while there may be an emerging consensus around what is called a "minimal" ideological position, other meanings remain equally active in discourse, leading to conceptual confusion. Second, using John Gerring's work on conceptual utility, ${ }^{20}$ I will argue that despite much work to help clarify and sharpen the concept, three central criticisms persist: (1) the term remains conceptually loose; (2) there is an unacknowledged normative bias equating democracy with its liberal variant; and, (3) in consequence, the term can simply become a label that sidelines challengers to the political status quo, ironing out crucial political, ideological, and programmatic differences key to discussion in the context of a "crisis of inequalities." Ultimately, then, questions remain about the utility of

\footnotetext{
${ }^{18} \mathrm{D}^{\prime}$ Eramo, "Populism and the New Oligarchy," p. 25.

${ }^{19}$ See for example Merkel's three democratic models in Wolfgang Merkel, "'Crisis of Democracy': Analytical Concept or Empty Signifier?" Paper presented to ECPR 8th General Conference, Glasgow, United Kingdom: ECPR (2014), pp. 3-7, available online at: https://ecpr.eu/Filestore/PaperProposal/0f0d1311-25e6-4cc2-964f-cdd44aa5ae6b.pdf.

${ }^{20}$ John Gerring, "What Makes a Concept Good? A Critical Framework for Understanding Concept Formation in the Social Sciences," Polity 31:3 (1999), pp. 357-93.
} 
the concept in such a context, questions which are particularly urgent, as its analytical use goes beyond regions traditionally associated with it, such as Latin America. ${ }^{21}$

I then illustrate these points empirically by providing a critical examination on commentary in the US media comparing Presidents Hugo Chávez of Venezuela and Donald J. Trump in the United States. Here, I argue that in these comparisons, analytical use of the term obscures the radical differences between both presidents on a contextual, ideological, political, and policy level, in favor of more weakly defined commonalities on discourse and style. The effect of this is to obscure much more fundamental discussions on the nature, content, and objectives of democracy, which in fact underlie this discussion. I then go on to show why this is important through a discussion on the concept of crisis. Here, I review Benjamin Moffitt's work on the role of crisis in theory on populism, and argue, through readings of work on the issue by Janet Roitman, Sylvia Walby, and Wolfgang Merkel, that crises are ill-defined periods, subject to temporal, definitional, and policy manipulation by hegemonic social forces through narrative and discourse. ${ }^{22}$ Work on populism, I argue, is in fact part of that wider discourse, with use of the concept shaping the discussion on the contemporary "crisis of inequalities" in support of a relatively unreconstructed liberal democracy, despite its role in helping such inequalities in the first place.

This leads to my speculating as to why populism remains a preferred explanatory and analytical concept for such differing political phenomena, despite its theoretical vagueness and lack of conceptual depth. Here, I argue that this is due to the concept's denigration of the popular and denial of the increasing gaps in the conditions of elites and ordinary people wrought by widening inequality. In other words, the concept provides very little critical challenge to the liberal ideological status quo, and indeed can uncritically support it. Yet, it is the former, not the latter role, which is a central duty of social scientists; particularly, in the current context of crisis. The best way to achieve this, I argue, is to restore the use of the left/ right dichotomy as the primary descriptor of political phenomena, rather than the catch-all conceptual vagueness of populism.

\section{Populism: The Theoretical Development of a Concept}

Populism, as is usually acknowledged, is a highly contested concept with distinct approaches to its study. This section will trace its emergence in the nineteenth century until the present to illustrate its complex, layered meanings in the literature, which ultimately contribute to its conceptual vagueness. The concept first emerged in reference to two distinct political phenomena in post-Civil War United States and in Tsarist Russia in the latter half of the nineteenth century. The American People's Party was founded in 1892, with an aim to represent farmers and workers who felt forgotten by the mainstream Democratic and Republican parties. ${ }^{23}$ As it

\footnotetext{
${ }^{21}$ See for example: Carlos de la Torre (ed.), The Promise and Perils of Populism: Global Perspectives (Lexington, KT: University Press of Kentucky, 2015); Benjamin Moffitt, The Global Rise of Populism: Performance, Political Style, and Representation (Stanford, CA: Stanford University Press, 2016); Cristóbal Rovira Kaltwasser and Cas Mudde, Populism in Europe and the Americas: Threat or Corrective for Democracy? (Cambridge, UK: Cambridge University Press, 2012).

${ }^{22}$ Benjamin Moffitt, "How to Perform Crisis: A Model for Understanding the Key Role of Crisis in Contemporary Populism," Government and Opposition 50:2 (2015) pp. 189-217; Janet Roitman, "Crisis," Political Concepts (2011), available online at: http://www.politicalconcepts.org/issue1/crisis/; Sylvia Walby, Crisis (Cambridge, UK: Polity, 2015); Merkel, "Crisis of Democracy."

${ }^{23} \mathrm{Tim}$ Houwen, "The Non-European Roots of the Concept of Populism," Working Paper No 120, Sussex European Institute, University of Sussex and Radboud Universiteit Nijmegen (2011), p. 9, available online at: https://www.sussex. ac.uk/webteam/gateway/file.php?name=sei-working-paper-no-120.pdf\&site=266.
} 
grew in popularity, it frequently was referred to by its adversaries as "populist," although the precise origins of the term are difficult to determine. ${ }^{24}$ Tim Houwen notes how the term generates both positive and negative connotations from these beginnings. ${ }^{25}$ On the one hand, the People's Party campaigned for the US Republic to be returned to the "people" as the holders of sovereignty. ${ }^{26}$ On the other, it was used to refer to those who appealed to the "common people" or the "mob" and was hence inherently anti-democratic. ${ }^{27}$ Hence, the term has a discursive purpose from the outset, in which both "positive and negative connotations can be distinguished," ${ }^{28}$ contributing to its conceptual looseness.

Similarly, the use of the concept "populist" to describe the narodnichestvo, which emerged in Tsarist Russia, is also disputed. The term has a specific and more general meaning: specific in that it refers to a "revolutionary movement of young intellectuals, who were resisting the Tsarist regime" around $1870 ;{ }^{29}$ generally, referring to a variety of revolutionary movements right up to the Bolshevik revolution of $1917 .^{30}$ Both shared the aim of enriching their ideas and practices through more direct contact with Russian peasants, whom they viewed as bearers of a more direct route to socialism, bypassing capitalism. How they both became labeled "populist" is disputed, however, and attempts to link them are analytically loose. ${ }^{31}$ Yet, both could be seen to be positive attempts to highlight and solve class grievances, rather than the negative attributes normally associated with populism.

The concept mostly falls into disuse thereafter, until, in the post-World War II period, it begins to acquire more general usage. According to Kenneth M. Roberts, there are four approaches or perspectives by which it is used from thence on. ${ }^{32}$ First, there is what he terms the historical/sociological perspective, emphasizing populism as a consequence of and necessary stage toward economic and social development. Second, there is the economic perspective, which identifies populism with expansionist and redistributive economic policies. A third perspective is a political perspective, which equates populism with vertical or leader-led popular mobilization at the expense of existing democratic institutions to foster direct leader/people communication. Fourth, there is what Roberts terms an ideological perspective, emphasizing an ideological discourse based on the "people" against those in power, the "underdog" against the "elite."

The historical/sociological perspective was led by Latin American analysts such as Gino Germani, Torcuato di Tella, and Octavio lanni. They argued that economic and social modernization in developing societies creates a situation of permanent change, which produces a "disposable mass" of people, usually from the newly urbanized popular classes. These, it is argued, are prone to support authoritarian leaders and/or movements, who then facilitate and encourage the mobilization and participation of the popular classes in the exercise of power. Notable in this perspective is a distinct distrust of the masses and their ability to recognize and support good government.

\footnotetext{
${ }^{24}$ Houwen, "Non-European Roots of Populism," p. 10.

${ }^{25}$ Ibid., 8.

${ }^{26}$ lbid.

${ }^{27}$ Ibid.

${ }^{28}$ Ibid., 12.

${ }^{29}$ Ibid., 13.

${ }^{30}$ lbid., 17.

${ }^{31}$ Ibid.

${ }^{32}$ Kenneth M. Roberts, "Neoliberalism and the Transformation of Populism in Latin America: The Peruvian Case," World Politics 48:82 (1995), pp. 82-116.
} 
Linked to this perspective is the economic perspective, whereby populism is associated with a policy of welfare and economic protectionism. It has a nationalist industrial and economic strategy, protecting jobs in local industry and, through nationalization, the control of local raw materials and key industries. By prioritizing local industrial growth and social welfare, it builds cross-class alliances, such as between the domestic industrial classes, the industrial working classes, or the bureaucratic and mercantile middle classes. By the 1980s, some viewed these polices as "fiscally irresponsible," as they ignored risks to inflation, balance of payments deficits and debts, and ultimately led to economic crises. ${ }^{33}$ Hence, populism here is associated with "profligate" state spending, which itself results from "unwise" popular demands, a persistent theme in much contemporary commentary, especially from those espousing fiscal austerity.

A third perspective is the political perspective, which posits the idea that the weaker democratic institutions are, the more likely populism will emerge, as the main function of institutions is to mediate between government and people. This can lead to people seeking strong executive leadership, a leader/people, top-down form of political organization. ${ }^{34}$ Furthermore, each instance of populism reinforces the original context of institutional weakness, thus paving the way for more populism. Populism then can become "a defining characteristic of a political culture." ${ }^{35}$ This perspective again harkens back to the irresponsible, gullible masses, choosing unsuitable leaders who beguile them with popular discourses, while hiding their personal power-hungry, authoritarian intent.

The final ideological perspective has two versions: the Laclauian post-Marxist version and more liberal versions. Ernesto Laclau's more positive version argues that the "populist rupture" is a moment whereby a path can be opened to establish a radical democratic state. ${ }^{36}$ The liberal version considers the Laclauian version "too vague $^{\prime 37}$ or too mechanistic in its assumptions and instead more negatively views populism as a form of ideology. ${ }^{38}$ Nevertheless, both recognize three principal elements as constituting populism: the leader, the people, and discourse linking the two.

For Laclau, populism is linked to a "crisis of the dominant discourse which is in turn part of a more general social crisis." ${ }^{39}$ In other words, populism emerges as a result of an ideological crisis of the dominant sectors within, and indeed caused by, a generalized economic and social crisis. He argues that the "people" are defined through the discourse of the leader, building relations between the different elements of a populist movement. ${ }^{40}$ This discourse consists primarily of an "appeal to the people" that aims to

\footnotetext{
${ }^{33}$ Roger Dornbusch and Sebastian Edwards (eds), The Macroeconomics of Populism in Latin America (Chicago, IL: University of Chicago Press, 1991); Jeffrey Y. Sachs, Social Conflict and Populist Politics in Latin America (San Francisco, CA: ICS Press, 1990).

${ }^{34}$ Nicos P. Mouzelis, Politics in the Semi-Periphery: Early Parliamentarianism and Late Industrialisation in the Balkans and Latin America (New York, NY: St. Martin's Press, 1986); George Philip, "New Populism in Spanish America," Government and Opposition 33:1 (1993), pp. 81-87, 96.

${ }^{35} J$ John Crabtree, "Populisms Old and New: The Peruvian Case," Bulletin of Latin American Research 19:2 (2000), pp. $163-76$.

${ }^{36}$ See for example: Ernesto Laclau, Politics and Ideology in Marxist Theory: Capitalism, Fascism, Populism (London, UK: Verso, 1977); Ernesto Laclau, On Populist Reason (London, UK; New York, NY: Verso, 2005); D.L. Raby, Democracy and Revolution: Latin America and Socialism Today (London, UK; Ann Arbor MI: Pluto Press, 2006) amongst others.

${ }^{37}$ Jan Werner Müller, "'The People Must Be Extracted from Within the People': Reflections on Populism," Constellations 2: 4 (2014), pp. 483-93.

${ }^{38}$ Ben Stanley, "The Thin Ideology of Populism," Journal of Political Ideologies 13:1 (2008), pp. 95-110.

${ }^{39}$ Laclau, Politics and Ideology, p. 175.

${ }^{40}$ Ibid.
} 
isolate mediating institutions and establish a direct unmediated relationship between the populist leader and the people.

Alternatively, Cas Mudde and Cristóbal Rovira Kaltwasser view populism as "a thincentered ideology that considers society to be ultimately separated into two homogenous and antagonistic groups, 'the pure people' versus 'the corrupt elite' and which argues that politics should be an expression of the volonté generale (general will) of the people." ${ }^{41}$ "Pure people" and "corrupt elite" are "empty vessels filled in different ways by different actors," and how these are filled can be used to identify subtypes of populism. ${ }^{42}$ These can be "left and right, be top-down or bottom-up, rely on strong leaders or even the leaderless." ${ }^{43}$ These analysts argue that their definition "travels well," allows the definition of sub-types of populism, and can link to supply-side and demand-side factors; thus, it can examine both leaders and the different constituencies, which support them in analyses. ${ }^{44}$ Ben Stanley similarly views it as a "thin-centered ideology" with similar component elements of leader, people, elite, and discourse; ${ }^{45}$ whereas, Jan Werner Müller argues that it is essentially "totalitarian" and therefore ultimately anti-democratic. ${ }^{46}$ Indeed, most such analyses (although not Laclau) seem to concur that populism is ultimately harmful for democracy and its institutions, and that this stems from a tendency by leaders to listen to the masses and act on their wishes in a manipulative, power-seeking manner. ${ }^{47}$

\section{Populism's Conceptual Utility}

Given these varying interpretations of the concept, is populism an effective tool for helping us understand contemporary politics? In addition, does it propose adequate diagnoses and solutions to its dilemmas and complexities, particularly, in a context of crisis? It is these questions which this section of the article seeks to address, using Gerring's criteria for assessing the utility of concepts in the social sciences. ${ }^{48}$

Gerring states that "concept formation lies at the heart of all social science endeavor" and therefore it is crucial that we form "good" concepts. ${ }^{49}$ A well-formed concept then is "an attempt to mediate among eight criteria: familiarity, resonance, parsimony, coherence, differentiation, depth, theoretical utility, and field utility." ${ }^{50}$ Hence, familiarity and resonance refer to recognition levels for both a lay or academic audience. Parsimony refers to the shortness both of the term itself (the extension) and, of its list of defining attributes (the intension). A coherent concept is one which is internally consistent between its instances and attributes; whereas, differentiation refers to the differences between those instances and the attributes from other most-similar concepts. In other

\footnotetext{
${ }^{41}$ Cas Mudde and Cristobal Rovira Kaltwasser, "Exclusionary vs. Inclusionary Populism: Comparing Contemporary Europe and Latin America," Government and Opposition 48:2 (2013), pp. 147-74.

${ }^{42}$ lbid.

${ }^{43}$ Ibid., 153.

${ }^{44}$ Ibid., 154.

${ }^{45}$ Stanley, "Thin Ideology of Populism."

${ }^{46}$ Werner Müller, "People Must Be Extracted from Within the People," p. 484.

${ }^{47}$ Michael L. Conniff, "Introduction: Toward a Comparative Definition of Populism," in Michael L. Conniff (ed.), Latin American Populism in Comparative Perspective (Albuquerque, NM: University of New Mexico Press, 1982), pp. 3-29; John Crabtree, "Populisms Old and New: The Peruvian Case," Bulletin of Latin American Research 19:2 (2000), pp. 16376; Roberts, "Populism and Democracy."

${ }^{48}$ Gerring, "What Makes a Concept Good?"

${ }^{49}$ Ibid., 359.

${ }^{50}$ Ibid., 367.
} 
words, how bounded, how operationalizable, is the concept? Depth refers to the number of accompanying properties that are shared by the instances under definition. Finally, theoretical utility denotes the level of usefulness within a wider field of inferences, and field utility within a field of related instances and attributes.

Regarding the first two criteria - familiarity and resonance - the concept of populism is certainly effective. As illustrated previously, populism has a high recognition factor judging by the number of references to it by politicians, the media, and in the academy. There is a strong cognitive link between "popular," "people," and "populism," which reinforces this resonance. Nevertheless, Herbert Gans, in his reflection on the term "underclass" in US social science and media, suggests that such criteria can have negative impacts on the conduct of research. ${ }^{51} \mathrm{He}$ outlines how increasing competition in the academy and in journalism in the post-World War II era led to pressures in the first to invent and popularize new concepts, and in the second to use and misuse these. He identifies two "dangerous characteristics" dynamic: journalists failing to "define terms," allowing readers to make their own, usually negative, inferences from their meaning, and a feedback loop whereby such negative connotations seeped into academic usage of the term. ${ }^{53}$ He notes how social scientists are often flattered when journalists and media use their terms (or their interpretation of terms) and such usage or exposure by the media does not go unnoticed by state funders of research at the hour of awarding grants. ${ }^{54}$ More pertinently still, he warns that if concepts become used for political purposes, "we run the danger of spoiling them for research purposes." ${ }^{155}$ In the end, what is most important is the creation of new ideas and new findings, and the best concepts are those which serve those ends, rather than familiarity and resonance, and the public attention these can draw. Gans therefore draws attention to the close and rather pernicious relationship between the academy, the media and, indeed, politics, and how each influences and conditions the behavior of the other. ${ }^{56}$

With regards to parsimony, while the term is short and to the point, its list of defining features, historically at least, has been extensive, as outlined in the last section. Nor has usage of the term in these different senses been abandoned; particularly, in media and political discourse. As Ezequiel Adamovsky points out: "In current usages [populism] refers to a family of ideologies, a variety of political movements, a type of regime, a ruling style, an economic model, and a particular mode of political appellation. ${ }^{\prime 57}$ As noted, more recent academic work has reduced the plethora of identifying features of the concept to three - the relation between leader and people forged through an anti-elite and/or anti-minority discourse. However, even these supposedly core characteristics of "people" and "elites" are questionable. Marco D'Eramo, for example, notes that Beppe Grillo of the Italian Five Star Movement, and exItalian Prime Minister Silvio Berlusconi have both been classified as populist, but have rarely, or ever, used the term "the people." ${ }^{58}$ Moreover, analyses of populism tend to treat "elites" as just

\footnotetext{
${ }^{51}$ Herbert J. Gans, "Uses and Misuses of Concepts in American Social Science Research: Variations on Loìc Wacquant's Theme of 'Three Pernicious Premises in the Study of the American Ghetto,'" International Journal of Urban and Regional Research 21:3 (1997), pp. 504-07.

${ }^{52}$ Ibid., 505.

${ }^{53}$ Ibid.

${ }^{54}$ Ibid., 507.

${ }^{55}$ Ibid.

${ }^{56}$ Ibid.

${ }^{57}$ Ezequiel Adamovsky, "Populism is Out of Control," Telesur TV (June 3, 2015), available online at: http://www.telesurtv. net/english/opinion/Populism-is-Out-of-Control-20150603-0042.html.

${ }^{58}$ D'Eramo, "Populism and the New Oligarchy."
} 
another minority - yet, this omits any examination of the immense power that these elites possess in so many different areas of social life, unlike vulnerable ethnic, religious, or sexual minorities. Indeed, criticism of elites is viewed as inherently dangerous - whereas, a case could be made, as William Sokoloff does, to argue that "popular hatred of elites is a good accountability mechanism and increases the legitimacy of the state." ${ }^{159}$

Furthermore, the identified peripheral attributes of different populist phenomena differ widely, diminishing the term's coherence further. For example, while rejections of elites may unite so-called right-populists and left-populists in Europe, their ideological underpinnings are fundamentally distinct. Right-populists emphasize the cultural, associating the notion of the people with the nation; whereas, left-populists associate it with class; $^{60}$ similarly, right-populists blame elites for increased immigration; whereas, leftpopulists blame them for economic and political inequalities. ${ }^{61}$ In other words, there is little coherence between so-called peripheral features, actual ideological content and resulting policy programs and the "populist" core features (people, elites, and so on) and peripheral features (actual policies) are disputed, diminishing the term's coherence.

Ben Stanley, ${ }^{62}$ Rovira Kaltwasser, and Mudde ${ }^{63}$ conceptualize populism as a "thin ideology" in order to circumvent this problem, arguing that populism, the "thin ideology," articulates itself with a "full" ideology - to give it programmatic depth. Yet, this innovative solution raises several problems. First, there is the question of how populists chose the "full" ideology with which they articulate themselves. Stanley argues that this depends on what is "salient" in a particular national context, what "resonates" in it. ${ }^{64}$ However, this does not explain how it is decided which issues are "salient" and which are not, nor why populists decide to focus on one or more "salient" issues over others. Missing entirely from this account is any suggestion of the specific power relations, national and transnational, which may exist within a national political space, their role in creating the conditions for the possible salience of some issues over others, and of a particular approach to that issue, and how the supposed populist phenomenon relates to these. In other words, "salience" is a result of hegemonic struggles over meaning amongst established powers within a given territory, and different political groups will be inserted into these struggles in different ways. In this conceptualization of populism, the issue of prioritization is equally problematic. If populism is the "thin ideology," why should this be privileged in the analysis of a particular political movement over the "full" ideology, which gives it its programmatic content? ${ }^{65}$ There are, therefore, real problems with the concept of populism in terms of its supposed parsimony.

Regarding differentiation, one of the main counter-referents for populism is democracy. Margaret Canovan ${ }^{66}$ famously claimed that populism is democracy's "shadow" and others its "specter" ${ }^{67}$ or its "mirror." ${ }^{18}$ Yet, populism and democracy are both poorly

\footnotetext{
${ }^{59}$ William W. Sokoloff, "In Defense of Hatred," New Political Science 37:2 (2015), pp. 163-80.

${ }^{60}$ Hanspeter Kriesi, "The Populist Challenge," West European Politics 37:2 (2014), pp. 361-78.

${ }^{61}$ Matthijs Rooduijn and Tjitske Akkerman, "Flank Attacks: Populism and Left-Right Radicalism in Western Europe," Party Politics 1:12 (2015), pp. 1-12.

${ }^{62}$ Stanley, "Thin Ideology."

${ }^{63}$ Mudde and Kaltwasser, "Exclusionary vs. Inclusionary Populism."

${ }^{64}$ Stanley, "Thin Ideology," pp. 105-06.

${ }^{65}$ See below for a fuller discussion on this in the context of the left/right dichotomy.

${ }^{66}$ Margaret Canovan, "'Trust the People!' Populism and the Two Faces of Democracy," Political Studies XLVII (1999), pp. 2-16.

${ }^{67}$ Benjamin Arditi, "Populism as a Specter of Democracy: A Response to Canovan," Political Studies 52:1 (2004), pp. 135-43.

${ }^{68}$ Francisco Panizza (ed.), Populism and the Mirror of Democracy (New York, NY; London, UK: Verso, 2005).
} 
bounded in most work on populism. First, as suggested previously, both can share similar characteristics, such as electoralism and a concept of representativity. ${ }^{69}$ "Democratic" leaders also use anti-elite discourse, and talk about the "people" ${ }^{70}$ while some so-called "populists" do not. ${ }^{71}$ Second, democracy itself is rarely defined by those writing on populism, yet democracy is, as Gerring points out, citing Robert A. Dahl, "a poxed term" precisely because of its essential contestability. ${ }^{72}$ Which democracy then do analysts refer to when they discuss populism? This is rarely made explicit, but the presumption usually is that it is liberal democracy or polyarchy. Third, not all parties or movements labeled populist are anti-democratic. Andrea Mammone clearly shows the anti-democratic, xenophobic, and racist nature of extreme far-right parties. ${ }^{73}$ Yet, the use of the term populist to describe radical left parties, with radical democratic policies, such as Podemos in Spain or Syriza in Greece, discursively links these parties to such neo-fascist parties, unwittingly or not. ${ }^{74}$ While some academics are careful to differentiate between left- and right-populism, ${ }^{75}$ the general usage of the term, especially in the media as well as in the academy, implies that "populism" is anti-democratic, even totalitarian as Müller claims, regardless of the programmatic content of the supposedly populist movement. ${ }^{76}$ This is essentially misleading as it irons out and obscures important distinctions in programmatic intent within the different instances being labeled populist, which have a direct bearing on democracy, pluralism, and tolerance in our societies.

Finally, it could be argued that the position presented here relativizes conceptual work. Is the bar of conceptual clarity and utility set too low, with the result that most political science concepts will not pass it? ${ }^{77}$ Yet, while most concepts are "essentially contestable," most will have some central characteristics that are accepted by the majority of analysts. ${ }^{78}$ Democracy, for example, may be as Dahl put it, a "poxed term," but most models of democracy will have elections at their core. ${ }^{79}$ Some analysts may argue about whether neoliberalism exists or not, or the extent to which it permeates social life, or whether it is "a consistent ideology at all." ${ }^{80}$ But, as Phillipp Ther convincingly argues, the conceptual core of neoliberalism remains the same: "privatization... and faith in the efficiency and rationality of the market.." ${ }^{81}$ As we have seen, populism has no such internal conceptual stability.

Ultimately, as Houwen shows in his wide-ranging conceptual history of "populism," struggles over the meaning of the term "do not only stem from the semantic variability

\footnotetext{
${ }^{69}$ Müller, "Reflections on Populism."

${ }^{70}$ Houwen, "Non-European Roots of the Concept of Populism," p. 31.

${ }^{71} D^{\prime}$ Eramo, "Populism and New Oligarchy," p. 15.

${ }^{72}$ Gerring, "What Makes a Concept Good?" p. 379.

${ }^{73}$ Andrea Mammone, "The Eternal Return? Faux Populism and Contemporarization of Neo-Fascism across Britain, France and Italy," Journal of Contemporary European Studies 17:2 (2009), pp. 171-92.

${ }^{74} \mathrm{See}$, for example, Luis Ramiro and Raul Gomez, "Radical-Left Populism during the Great Recession: Podemos and Its Competi-tion with the Established Radical Left," Political Studies 65:15 (2017), pp. 108-26; Giorgos Katsambekis, "Radical Left Populism in Contemporary Greece: Syriza's Trajectory from Minoritarian Opposition to Power," Constellations 23:3 (2016), pp. 391-403 for the respective Spanish and Greek cases.

${ }^{75}$ For example: Mudde and Kaltwasser, "Exclusionary vs. Inclusionary Populism."

${ }^{76}$ Müller, "Reflections on Populism."

${ }^{77}$ Thanks to one of the reviewers for making this point.

${ }^{78}$ William B. Gallie, "Essentially Contested Concepts," Proceedings of the Aristotelian Society 56:1 (1955), pp. 167-98.

${ }^{79}$ Merkel, "Crisis of Democracy."

${ }^{80}$ Phillipp Ther, Europe Since 1989: A History (Princeton, NJ; Oxford, UK: Princeton University Press, 2016), p. 99.

${ }^{81}$ Ibid.
} 
of the concept, but also from political struggles to define the word." ${ }^{\prime 2}$ Perhaps, it is those political struggles we should be discussing, rather than the meaning of "populism." Indeed, the current situation of crisis demands that our analysis goes beyond just talk of populism to much deeper questions such as: How can democracy help solve the "crisis of inequalities"? How must it change and adapt to do so? Indeed, what type of democracy do we need to help tackle this crisis? This point will become further apparent if one examines academic discourse on comparing Hugo Chávez and Donald Trump as populists.

\section{Chávez and Trump: Two of a Kind?}

Coming up to, and beyond, the November 2016 US general elections, which as is well known Donald J. Trump went on to win, a slew of media articles in mostly US media outlets were published comparing Trump with the late Venezuelan president Hugo Chávez (1954-2013) as populists. This section will review a number of those found through a time-bound internet search using Lexis Nexis, with the names Trump/ Chávez in the title. Here, I will first review the majority of these, endorsing the comparison, and then those which reject it or have reservations about it, before going on to discuss these positions in the context of the argument advanced so far.

Those who fully endorse the comparison characterize both men along four main lines. ${ }^{83}$ First, they see both men as strong leaders with authoritarian tendencies, which ultimately undermine existing institutionality. Second, they accept that there are important ideological and policy differences between them, but argue that these differences are largely irrelevant, as they share a common "populist" ideological position that the "people" shall rule and that the elites and/or minorities shall not interfere with that rule. Third, both Chávez and Trump use discourse as a strategy to achieve power, which is anti-pluralist in nature, dividing the social space into the "people vs. the elite." However, "the people" in each country is composed of differing groups: Chávez argued in defense of the "downtrodden" and "non-white," whereas Trump favors "white Christians." While for Chávez, the enemy was the elites, for Trump it is racial and religious minorities and immigrants from

\footnotetext{
${ }^{82}$ Houwen, "Non-European Roots," p. 3.

${ }^{83}$ Alberto Barrera Tyska, "What Hugo Chávez Tells Us About Donald Trump," The New York Times (September 20, 2016), available online at: https://www.nytimes.com/2016/09/21/opinion/what-hugo-chavez-tells-us-about-donald-trump. html?action=click\&contentCollection=Opinion\&module=RelatedCoverage\&region=EndOfArticle\&pgtype=article; Rory Carroll, "Insult, Provoke, Repeat: How Donald Trump Became America's Hugo Chávez," The Guardian (June 22, 2016), available online at: https://www.theguardian.com/us-news/2016/jun/22/donald-trump-hugo-chavez-politicalsimilarities; Carlos de la Torre, "Will Democracy Survive Trump's Populism? Latin America May Tell Us," The New York Times (December 15, 2016), available online at: https://www.nytimes.com/2016/12/15/opinion/will-democracy-sur vive-trumps-populism-latin-america-may-tell-us.html; loan Grillo, "Is Donald Trump an American Hugo Chávez?" The New York Times (November 4, 2016), available online at: https://www.nytimes.com/2016/11/04/opinion/is-donaldtrump-an-american-hugo-chavez.html; Sean Illing, "Trump Ran As A Populist. He's Governing As An Elitist. He's Not The First," Vox (June 23, 2017), available online at: https://www.vox.com/2017/6/23/15791432/donald-trump-popu lism-latin-america-republican-party; Jennifer McCoy, "COLUMN-What Hugo Chávez and Donald Trump Have in Common," Reuters (March 31, 2016), available online at: https://www.reuters.com/article/mccoy-chavez/columnwhat-hugo-chvez-and-donald-trump-have-in-common-idUSL2N1731U1; Andrés Miguel Rondón, "To Beat President Trump, You Have to Learn to Think Like his Supporters," The Washington Post (December 26, 2017), available online at: https://www.washingtonpost.com/news/posteverything/wp/2017/12/26/to-beat-president-trump-you-have-tolearn-to-think-like-his-supporters/?utm_term=.8f0cbc8cb19c; Joel Simon, "What Does Trump Have in Common With Hugo Chavez? A Media Strategy," Columbia Journalism Review (February 17, 2017), available online at: https://www. cjr.org/opinion/trump-chavez-media.php.
} 
"shithole" countries. Fourth, both leaders have a common media strategy, whereby, on the one hand, both manipulate the media through a variety of tactics and "stunts" to gain attention, but on the other, they attack any media which question them and their behavior. ${ }^{84}$ Cumulatively, these characteristics and tactics undermine democratic "checks and balances," capturing, for example, the judiciary and attacking civil society, in order to control political power. The overall result is a highly polarized society which, in Venezuela, led to a "slowly strangled democracy" and ultimately authoritarianism. ${ }^{85}$ Americans therefore need to be vigilant that Trump does not do the same. Returning to the distinct analytical perspectives to populism outlined previously, these approaches to the two leaders are a combination of the political and ideological with their emphasis on top-down, manipulative leadership and the use the concept of the "people" against elites and minorities.

Those who reject the comparison, or parts of it, argue that there are radical differences in terms of the class and racial background of the two men, in their ideological and policy stances, ${ }^{86}$ and even in their levels of intelligence. ${ }^{87}$ In terms of origins, both Tim Gill and Pablo Vivanco point out that Trump's wealthy, white family background contrasts markedly to Chávez's poor, mixed race family, which inevitably shaped their respective political approaches. ${ }^{88}$ Trump, therefore, is decidedly pro-free market, using the state to enrich the already rich; whereas, Chávez used the state to right market-created inequalities and poverty, by directing resources to the poor. Chávez, moreover, consistently aimed to include minorities, such as the indigenous, or to end discrimination, such as against women; whereas, Trump seeks to exclude and scapegoat minorities, is heavily supported by white supremacists and neo-Nazis, and, rather than supporting women's political struggles for equality, seeks to "grab [them] by their pussies." Additionally, regarding refugees, Chávez began the task of nationalizing some of the five million Colombian refugees living in Venezuela, and provided access to social programs for all these refugees regardless of their legal status. Trump, on the other hand, demonizes refugees and migrants and is seeking to expel millions of them, and to build a wall on the US-Mexican border ostensibly to stop more arriving. Finally, Vivanco argues that during his presidency, Chávez consistently advocated for peace, despite his military background. He spoke out against the US-led invasion of Afghanistan in 2001 and of Iraq in 2003, and had an active participation in the Colombian peace process. Trump, on the other hand, is bellicose in his rhetoric, using the threat of war as a negotiating strategy and aiming to massively increase military spending..$^{89}$ Gill, however, accepts that there are similarities in terms of both men's rhetoric and style, as well as in terms of their autocratic centralization

\footnotetext{
${ }^{84}$ Barrera Tyska, "What Hugo Chávez Tells Us About Donald Trump."

${ }^{85}$ Carlos de la Torre, "Will Democracy Survive Trump's Populism?"

${ }^{86}$ Pablo Vivanco, "5 Reasons Why Comparing Trump to Hugo Chávez Is Nonsense," Telesur (October 20, 2016), available online at: https://www.telesurtv.net/english/analysis/5-Reasons-Why-Comparing-Trump-to-Hugo-Chavez-Is-Nonsense20161020-0023.html; Tim Gill, "People Are Comparing Donald Trump To Hugo Chávez. That's Mostly Wrong," The Washington Post (October 17, 2016), available online at: https://www.washingtonpost.com/news/monkey-cage/wp/ 2016/10/17/people-are-comparing-donald-trump-to-hugo-chavez-thats-mostly-wrong/?utm_term=.47aaeb1a4eac.

${ }^{87}$ John Patrick Leary, "No, Donald Trump is Not Hugo Chávez," Venezuelanalysis (October 24, 2016), available online at: https://venezuelanalysis.com/analysis/12738.

${ }^{88}$ Gill, "People are Comparing"; Vivanco, "5 Reasons."

${ }^{89}$ Vivanco, ibid.
} 
of power in the office of the president; but, these similarities shall not overshadow the aforementioned important background, ideological, and policy differences. ${ }^{90}$

In this article, I have argued that populism's conceptual usefulness can be subject to three central criticisms: its conceptual looseness; its normative bias equating democracy with its liberal variant; and, its use as a label to side-line challengers to the status quo. The overall effect is to stymie and curtail necessary discussion on what I have called the "crisis of inequalities" and its relation to democracy. The debate comparing Trump and Chávez as populists, I argue here, confirms the validity of these criticisms.

Regarding populism's conceptual looseness, this debate confirms a consensus around the political and ideological approaches to populism, and reveals a variety of weaknesses inherent to these approaches. Earlier, I argued that populism had problems regarding its parsimony and its differentiation, specifically with reference to democracy, and in the Trump/Chávez debate, these problems are encountered again. With regards to parsimony, while there is an agreed core of attributes around the leader/people nexus within the debate, this is prioritized at the expense of the very wide ideological and policy differences between the two. This is justified due to the outcomes of the leader/people discursive nexus, which, it is argued, ineluctably leads to exclusion and, eventually, authoritarianism. However, as Gabriel Hetland points out, in a debate led by David Smilde on the comparison between the two leaders, a key similarity between both leaders "is that there are inclusionary and exclusionary elements within both...." ${ }^{91}$ In the case of Chávismo, the poor have been included, while elites and any oppositional elements are excluded; for Trump, the opposition is also excluded, but there are also attempts to include "certain valid working class grievances related to those who have lost out vis-a-vis trade, etc." ${ }^{12}$ Populism then can contain "quite contradictory elements of both inclusion and exclusion and popular empowerment and elite control." 93

Hetland's observation indeed points to the following key criticism regarding the conceptual use of populism: its poor boundedness vis-a-vis other concepts; in particular, democracy. In effect, all politics deals with inclusion/exclusion, because, as Lasswell famously observed, politics is about deciding "who gets what." Inevitably, then, some will be excluded and some included at the time of policymaking with accompanying rhetoric to justify this. D'Eramo points out, for example, that US President Franklin Delano Roosevelt used discourse to justify the introduction of policies protecting workers and limiting corporate and financial power. ${ }^{95}$ In the current context, many conservative leaders rhetorically divide the social space into two: US Republican Speaker Paul Ryan into "takers and makers"96; George Osborne, (ex-) United Kingdom (UK) Conservative Chancellor between "strivers and

\footnotetext{
${ }^{90}$ Gill, "People are Comparing."

${ }^{91}$ Gabriel Hetland contribution to David Smilde, "Debate on the Hugo Chávez / Donald Trump Comparison," WOLA Venezuelan Politics and Human Rights Blog (November 6, 2016), available online at: https://venezuelablog.org/debateon-the-hugo-chavez-donald-trump/.

${ }^{92}$ Ibid.

${ }^{93}$ Ibid.

${ }^{94}$ Harold D. Lasswell, Politics: Who Gets What, When, How (New York, NY; London, UK: Whittlesey House, McGraw-Hill Book Co, 1936).

${ }^{95} \mathrm{D}^{\prime}$ Eramo, "Populism and New Oligarchy," p. 13.

${ }^{96}$ Mother Jones Video, "Paul Ryan's 47 Percent: The 'Takers' vs. the 'Makers'," Youtube (October 5, 2012), available online at: https://www.youtube.com/watch?v=vZVfb7Cd4dg.
} 
skivers" ${ }^{\prime 97}$; and, Leo Varadkar, current Irish Taoiseach (Prime Minister), into "those who pay for everything, and those who pay nothing and expect everything for free." ${ }^{98}$ All three of these conservative politicians then divide the social space, excluding some (usually the poor) while seeking to include others (that is the "middle class" and the rich); yet, none of these are considered "populist." It seems, then, that only those who seek to favor the poor over the wealthy are considered populist, despite similar dividing tactics used by those who favor the rich, suggesting a selective bias in application of the concept rather than a strictly social scientific rationale.

Within almost all contributions to the Trump/Chávez debate, democracy is taken as equivalent to its liberal variant, with the pronounced emphasis on the need for pluralism and checks and balances on the executive. Yet, the previous observation raises questions on the ability of liberal democracy to deal adequately with the problem of inequality. In those contributions which argued in favor of the comparison, there was little discussion on this key point. Many did recognize that inequalities were causes for the emergence of both presidents, but these were usually afterthoughts and very few indeed suggested alternatives. Andrés Miguel Rondón argues, somewhat condescendingly, in one of his opinion pieces, that groups opposing populist leaders need to go to where the poor live and participate in things which they enjoy, such as (in Venezuela) playing dominos, dancing salsa, or playing baseball. ${ }^{99}$ Jennifer McCoy observes that both Trump and Chávez emerged out of "a devastating recession and a decades-long trend of deepening income inequality and social immobility." ${ }^{100}$ Rory Carroll acknowledges that populists can help "spur a much-needed shake-up of complacent parties." ${ }^{101}$ None of these analysts and commentators, however, offers any indication as to how these parties should respond to the issue of inequalities. The implication is that only liberal democracy can deal with this problem, even when it is from within that system that policies encouraging inequality have been implemented. While some see populists as classic "bait and switchers," "campaigning like populists, but governing like elites,"102 there are many social democratic parties in Europe, for example, which have done the same. ${ }^{103}$

In effect, as Smilde points out, the Trump/Chávez discussion is a debate between the prevalence of form or of content in conceptions of democracy. The political scientists concentrate on formal, institutional aspects of democracy (form), while sociologists "focus on the substantive elements of democracy, i.e., inequalities," (content). ${ }^{104}$ The

\footnotetext{
${ }^{97}$ The Telegraph, "George Osborne Attacks Welfare Cuts Critics," Youtube (April 2, 2013), available online at: https:// www.youtube.com/watch?v=ux9pbfBtbQo.

${ }^{98}$ Patrick Cotter, "Leo Varadkar Extreme Rightist," Youtube (June 1, 2017), available online at: https://www.youtube.com/ watch? $=$ WCsC5r51.jpc.

${ }^{99}$ Andrés Miguel Rondón, "In Venezuela We Couldn't Stop Chávez, Don't Make the Same Mistake We Did," The Washington Post (January 27, 2017), available online at: https://www.washingtonpost.com/posteverything/wp/2017/01/27/in-venezuela-wecouldnt-stop-chavez-dont-make-the-same-mistakes-we-did/?utm_term=.c0262243aeea.

${ }^{100}$ McCoy, "Chávez and Trump in Common."

${ }^{101}$ Carroll, "Insult, Provoke, Repeat."

${ }^{102}$ Illing, "Trump Ran as a Populist."

${ }^{103}$ Examples would be the French Socialist party under Francoise Hollande; German Social Democratic Party (SPD) under Gerhard Schroeder; the Italian Democratic Party led by Matteo Renzi; and, the Irish Labour Party under Eamonn Gilmore, amongst others. All, except Schroeder, were severely punished at the polls, although the SPD has never won a federal election since 2005.

${ }^{104}$ Smilde, ibid.
} 
discussion then is less about these two leaders and more about the very nature of democracy itself. ${ }^{105}$ Smilde concludes that "the exclusionary political tactics of populism will eventually undermine whatever progress was made in terms of the 'other' inequalities," culminating in authoritarianism. ${ }^{106}$ Yet, this fails to acknowledge the responsibility of liberal democracy for deepening these inequalities and the lack of adequate responses from liberal democratic political actors as to how or even if they may remedy them. In other words, the problem becomes populism, rather than the critical issues around inequality, which give rise to the phenomena branded as "populism," and the solution offered is simply to get rid of the "populist." In this way, the Trump/Chávez debate underscores my earlier point: that necessary discussion on the "crisis of inequalities" is side-tracked into futile comparisons between very different political phenomena, and facile short-term solutions are offered in lieu of fundamental policy reviews on the key issues within this crisis and the capacity of actually existing democracy to deal with these effectively.

\section{Populism in a Context of Crisis}

Why then does theory on populism eschew discussion on the "crisis of inequalities" in favor of futile comparisons of widely differing political reactions to this crisis? Indeed, does theory on populism admit crisis as a cause of so-called "populism?" This is important, as a key argument in this article is that populism is not useful as a concept to deal with a context of crisis. In this section, then, I will first discuss the role crisis plays in theory on populism as analyzed by Moffitt. ${ }^{107}$ Moffitt identifies three views on the role of crisis in the literature on populism: causal, agnostic, and skeptical. He adds his own fourth view, arguing that crisis is internal to populism, as populists seek to "perpetuate crisis" in their own interests. In response to this, I will argue, reviewing work by Roitman, ${ }^{108}$ Walby, ${ }^{109}$ and Merkel $^{110}$ that crises are ill-defined periods subject to temporal, definitional, and policy manipulation by hegemonic social forces through narrative and discourse. Rather than seeing crisis as internal to populism, as Moffitt does, I will argue that the use of the concept of populism itself in academic, media, and political discourse is part of this wider hegemonic struggle to define crisis and settle its outcomes.

Crisis has long been a central but disputed element in theories on populism. Moffitt identifies three positions on the relationship between populism and crisis, four when we include his own position. ${ }^{111}$ The first, evident in the discursive and political approaches to populism, sees crisis as an essential or important causal element in the emergence of populism. Second, there is an "agnostic" position held by those who take what Moffitt calls a minimalist, or what I have termed an "ideological" approach to populism, which acknowledges the role of crisis in "setting the scene" for populism, but does not see "the relationship between them as necessarily causal." ${ }^{112}$ Finally, a

\footnotetext{
${ }^{105}$ Smilde, "Trump/Chávez Debate."

${ }^{106}$ Smilde, ibid.

${ }^{107}$ Moffitt, "How to Perform Crisis."

${ }^{108}$ Roitman, Crisis.

${ }^{109}$ Walby, Crisis

${ }^{110}$ Moffitt, "Crisis of Democracy."

${ }^{111}$ Moffitt, "How to Perform Crisis."

${ }^{112}$ Ibid 194.
} 
third position, held by those such as Knight or Arditi, rejects outright the link between crisis and populism. ${ }^{113}$ Knight argues that the concept of crisis is too vague to be of any analytical value; whereas, Arditi feels that concentrating on crisis runs the risk of excluding populist phenomena, which do not use crisis as a central part of their appeal to the electorate. Moffitt's own contribution is that these previous positions view crisis as something external to populism; whereas, he sees it as internal. He agrees that crisis is an elusive concept, but argues, following Reinhart Kosseleck, Roitman, and Colin Hay, that it can only be "experienced through performance and mediation." ${ }^{114}$ This means that "populist actors actively perform and perpetuate a sense of crisis, rather than simply reacting to external crisis." ${ }^{115}$ In this way, crisis is "a central feature of the phenomenon itself." ${ }^{\prime 16}$

Yet, a factor that Moffitt neglects to consider is if actual discourse and discussion on populism is in itself part of a greater and more wide-ranging discussion on crisis and the meaning of democracy. Both Roitman and Walby, for example, concur that while crises are real events - with real, devastating implications for real people - their meaning is socially constructed through discourses and narrative. ${ }^{117}$ The actual narrative of a crisis how it happened and why it happened - is a site of hegemonic struggle between different social forces, with the victors ultimately defining the crisis and, more importantly, the social settlement which emerges from it.

Merkel looks more specifically at the concept of "crisis of democracy" and its relation to inequality. He defines crises as "system-threatening....when challenges to democracy....produce actors who have the resources and strategic capabilities to confront the important power elites of the old system." ${ }^{118}$ While he remains agnostic on the existence of such a crisis in the present context, he does find challenges in three areas central to democracy's good functioning: participation, representation, and governance. ${ }^{119}$ In terms of the first, sharp rises in socio-economic inequality have been rapidly translated into political inequality with the result that the "disadvantaged lower strata of society do hardly anything to make their voice heard and heard effectively against this development." 120 The results are "simulative democracies," with hollowed out democratic institutions. ${ }^{121}$ Governance structures meanwhile are dominated by globalized markets and supranational political institutions, such as the European Union, whereby the "former operate in the individual pursuit of profit, [while] the latter have so far not been democratized to any considerable degree." ${ }^{122}$ As a result, he warns that:

the equality principle of democracy has been affected by two-fold oligarchization: socioeconomically driven political self-exclusion of the lower classes and the self-liberation of the top 1 per cent.... of the income hierarchy from the social responsibility that comes with property, accompanied by maximal political influence. ${ }^{123}$

\footnotetext{
${ }^{113}$ |bid.

${ }^{114}$ Ibid., 195.

${ }^{115}$ lbid.

${ }^{116}$ Ibid., 195.

${ }^{117}$ Roitman, "Crisis"; Walby, Crisis.

${ }^{118}$ Merkel, "Crisis of Democracy," p. 19.

${ }^{119}$ Ibid.,18-20.

${ }^{120}$ Ibid., 18.

${ }^{121}$ Ibid.

${ }^{122}$ Ibid., 19.

${ }^{123}$ Ibid.
} 
This "reduced form of democracy" may escape acute crisis "for the moment," but in the long term, it will make it a much less attractive form of government, as it will not be fulfilling its function to "constantly monitor and correct inequalities in income and life chances," which political equality is supposed to ensure. ${ }^{124}$

Merkel's account therefore, along with Roitman and Walby, implies a role for narrative and discourse in the identification and characterization of crises. ${ }^{125}$ Yet, Merkel also points to two real problems in the exercise of democracy. First, he illustrates the need to integrate, as Walby insists, analyses from other domains, such as the economic and the social, into our political analysis, in order to arrive at a more accurate macro view of the contemporary state of democracy. ${ }^{126}$ Second, we need to evaluate the role of the many political organizations labeled "populist" from a non-normative and empirical perspective, that is, to examine the extent to which each of these can contribute or not to the quality of our democracies in this more macro sense. The argument until now suggests that the concept of populism fails on both these counts. First, as illustrated by the Trump/Chávez discussion previously, form is prioritized over substance in theory on populism. Second, theory on "inclusive" or "exclusive" populism is too diffuse to balance the dominance of liberal institutionality in populist theory, with little integration of the economic and social domains into its overall theoretical arc. Third, and finally, this emphasis on institutionality emerges from a normative bias in defense of liberal democracy as the only possible democracy, and fails to assess and learn from integrative measures and mechanisms taken by governments labeled populist on their own terms. Examples here would be the many innovative participatory and direct democracy mechanisms instituted in some left-led Latin American countries, including Constitutional Assemblies, procedures for recall of public representatives, community councils in Venezuela, and the notion of "plurinationality" in Bolivia to help encompass different ethnicities and cultures into one political space. ${ }^{127}$ In the literature on populism, the value of such experiments is largely dismissed as simply part of the manipulative scheming by the populist leader to undermine liberal institutions and perpetuate his own autocratic power, rather than as possible valuable lessons as to how actually existing democracy can adapt to survive.

\section{Conclusion: Must We Talk about Populism?}

In this article, I have sought to critically examine the concept of populism and its overwhelming popularity amongst media, politicians, and, in particular the academy. First, I provided an overview of conceptual work on populism, demonstrating how an ideological usage is now dominant, emphasizing the core elements of the "pure" people,

\footnotetext{
${ }^{124}$ Ibid., 20.

${ }^{125}$ Roitman, "Crisis"; Walby, Crisis.

${ }^{126}$ Walby, ibid.

${ }^{127}$ For discussions on these see Jennifer Leigh Disney and Virginia S. Williams, "Latin American Social Movements and a New Left Consensus: State and Civil Society Challenges to Neoliberal Globalization," New Political Science 36:1 (2014), pp. 1-31; on Venezuela see for example Michael M. McCarthy, "The Possibilities and Limits of Politicized Participation: Community Councils, Coproduction, and Poder Popular in Chávez's Venezuela," in Maxwell A. Cameron, Eric Hershberg, and Kenneth E. Sharpe (eds), New Institutions for Participatory Democracy in Latin America (New York, NY: Palgrave Macmillan US, 2012); on Bolivia see Walter Arteaga, "Building Citizenship in the Context of the Debate on the Post-2015 Agenda in Bolivia," Community Development Journal 50:4, pp. 571-88, to provide just some suggestions on the rich literature available on these approaches to democracy.
} 
the "corrupt" elite, and the use of discourse to establish links between leader and people. This is also associated with a political usage, or the charismatic strong leader and the subservient masses. Nor are previous sociological or economic usages forgotten, but rather persist in media and political circles.

I then used Gerring's criteria of conceptual goodness to argue three points. ${ }^{128}$ First, that the concept is conceptually loose, leading to the inclusion of many movements, parties, and leaders which have, in fact, little in common and, often, do not satisfy basic criteria. Second, that analysis is usually informed by an unacknowledged normative bias equating democracy with its liberal variant, despite the existence of distinct philosophical and theoretical approaches to its realization. Third, the concept acts as a label that marginalizes political movements challenging the political status quo regardless of their ideological positions or programmatic proposals. This, I argue, stifles debate necessary in a time of increasing uncertainty and crisis, most notably around the nature of democracy and how inequality relates to democracy. In effect, the problems underpinning the crisis are supplanted by concern about "populism" itself. Indeed, "populism" becomes the crisis, rather than the underlying issues that have led to it, and the solution deemed simply to get rid of the "populist."

Following on from this discussion, I illustrated these contradictions through an examination of various opinion articles in the US media comparing Presidents Trump and Chávez. Here, I argued that these pieces displayed characteristics of the ideological and political views of populism, concentrating on how both presidents undermine the formal, institutional aspects of democracy, while de-emphasizing issues around substantive democracy relating to greater levels of socio-economic inequality. I concluded that ultimately these discussions were about the very nature of democracy, and, most importantly, its response to the "crisis of inequalities," but that this more fundamental discussion is obscured by a normative discussion around the supposed dangers of populists.

Finally, I interrogated the concept of crisis as this is central to theorizing on populism, although rarely examined in depth. Here, I concluded that crises were ill-defined periods, subject to temporal, definitional, and policy manipulation by hegemonic social powers through narrative and discourse. I concluded that while Moffitt argued that crisis was internal to populism, discussion on populism was itself internal to crisis. In other words, the use of the concept diverts attention away from the aforementioned fundamental questions on democracy and its relation to inequality. Social scientists therefore need to respond to this debate with more conceptual rigor. The question then is: Which concept or concepts could provide this? Here, I argue that a return to a simple left/right dichotomy is the best means to order political phenomena.

It is fashionable in the present context to argue that the left/right dichotomy shall be abandoned, and theory on populism certainly contributes to that trend, collapsing left and right in its over-arching term. I argue otherwise. Norberto Bobbio views inequality as fundamental to the left/right distinction. ${ }^{129}$ Those on the left view inequalities as natural but modifiable through policy; whereas, those on the right view them as necessary, but inconsequential in a context of the rule of law. Alan Noël and Jean-

\footnotetext{
${ }^{128}$ Gerring, "What Makes a Concept Good?"

${ }^{129}$ Norberto Bobbio, Left and Right: The Significance of a Political Distinction (Cambridge, UK: Polity, 1996).
} 
Phillipe Therién ${ }^{130}$ see the dichotomy as "unavoidably inherent in political life and foundational for democracy,"131 allowing a "structured conversation" without which "political debates tend to remain inchoate, and centered on personalities, images, and patronage." ${ }^{132}$ It is, hence, the "core currency of political exchange [providing] a simple and universal language that helps citizens, politicians and experts make sense of politics." ${ }^{133}$ The concept of populism, I argue here, contributes to such inchoate political debates, by ironing out these fundamental differences, effectively eliding it from discussion.

Even when it is integrated into theory, it ends up overshadowed by the catch-all vagueness of populism. As discussed earlier, Mudde and Rovira Kaltwasser's differentiation between "inclusionary" or "exclusionary" populism remains diffused as these are not so easily separated analytically and are indeed inherent in all politics. Moreover, the term populism remains the main explanatory concept, and the left/right dichotomy residual, obscuring the primary ideological indicators of the political phenomenon under study. Mammone makes this very point in his interrogation of the use of populism to describe what he terms as "right-wing extremist" groups in Europe. ${ }^{134} \mathrm{He}$ argues that the use of the term populist to describe these parties runs the risk of "over-simplifying their party philosophies, decontextualising analysis, and by-passing their 'burden of the past."'135 Rather than populist, these movements are in effect "a contemporarization of neofascism within a post-materialist and global society" and should be recognized as such. ${ }^{136}$ Attaching the label populism to them as the descriptive signifier, only obscures these more salient and important characteristics; recognizing them as "right-wing," however, brings them to the fore and helps differentiate them more sharply from radical left political expressions. A prioritization of the left/right dichotomy in analysis, therefore, brings much greater conceptual clarity than populist categorizations.

It is unlikely, however, that the dominance of populism as a concept in political discourse will wane any time soon. As I discussed previously with regard to Gans, the concept is too deeply embedded in the nexus between the media, politics, and the academy to be easily dislodged from its dominance. ${ }^{137}$ This is no accident, as it provides the intellectual support for a false distinction between a so-called, auto-denominated, "moderate center" and its supposed extremes on left and right. ${ }^{138}$ Populism, indeed, has become a heuristic device to help perpetuate what Tamás identifies as "the elite's uprising against The People, and not vice versa." ${ }^{139}$ In this article, I have defined populism as a theoretical academic tradition used, intentionally or not, to negatively counterpose electorally democratic but non-liberal political organizations over the existing liberal democratic parties, despite the role the latter have had in the production

\footnotetext{
${ }^{130}$ Alain Noël and Jean-Phillipe Therién. Left and Right in Global Politics (Cambridge, UK: Cambridge University Press, 2008).

${ }^{131}$ Ibid., 231-32.

${ }^{132}$ Ibid., 234.

${ }^{133}$ Ibid., 198

${ }^{134}$ Mammone, "Eternal Return?"

${ }^{135}$ Ibid., 185.

${ }^{136}$ Ibid., 187, emphasis in original.

${ }^{137}$ Gans," Uses and Misuses of Concepts."

${ }^{138} \mathrm{D}^{\prime}$ Eramo, "Populism and the New Oligarchy."

${ }^{139}$ Gáspár Miklós Tamás, "The Mystery of 'Populism' Finally Unveiled" (February 24, 2017), available online at: https:// www.opendemocracy.net/wfd/can-europe-make-it/g-m-tam-s/mystery-of-populism-finally-unveiled.
} 
of the very inequalities which give rise to the former in the first place. The choice then for social scientists, in using the concept of populism, is between helping perpetuate the elite revolt identified by Tamás, or to seek more effective, precise conceptual tools to help ordinary citizens resist the continued embedding of oligarchical rule into our democratic structures.

\section{Acknowledgments}

I would like to thank the journal editors and anonymous peer reviewers, and Timofey Agarin, Queen's University, Belfast, UK, Tim Gill, the University of North Carolina at Wilmington, USA, and Christopher Wylde, Richmond, the American International University in London, UK, who reviewed various drafts of this article.

\section{Disclosure statement}

No potential conflict of interest was reported by the author.

\section{Notes on contributor}

Barry Cannon (PhD, Dublin City University) lectures on politics in Maynooth University, Ireland. His research focuses on Latin American politics, especially civil society, democratization, and the left and right axis in the region. He has published in a number of key journals including Third World Quarterly, Latin American Politics and Society, and Democratization. His most recent book is The Right in Latin America: Elite Power, Hegemony and the Struggle for the State (Routledge, 2016).

\section{ORCID}

Barry Cannon (D) http://orcid.org/0000-0002-5205-6634 